\title{
Development of an Immunomagnetic Electrochemical Sensor for Detection of BT-CRY1AB/CRY1AC Proteins in Genetically Modified Corn Samples
}

\author{
G. Volpe \\ Dipartimento di Scienze e Tecnologie Chimiche, Università degli Studi di \\ Roma "Tor Vergata", Roma, Italy \\ N. H. Ammid \\ Department of Chemistry, Garyounis University, Benghazi, Libya \\ D. Moscone, L. Occhigrossi, and G. Palleschi \\ Dipartimento di Scienze e Tecnologie Chimiche, Università degli Studi di \\ Roma "Tor Vergata", Roma, Italy
}

\begin{abstract}
The aim of the present work was the development of an immunomagnetic electrochemical sensor (IMES) for a simple and fast detection of Bt-Cry1Ab/Cry1Ac proteins in genetically modified corn flour. The IMES is based on a sandwich format using magnetic beads as immobilization support and disposable screen-printed electrodes (SPEs) as electrochemical transducers. An alkaline phosphatase labeled antiglobulin $\left(\mathrm{Ab}_{2}-\mathrm{AP}\right)$ was used to reveal the sandwich complex between monoclonal anti-Cry1 $\mathrm{Ab}$ antibodies (MAb), Cry1 Ab protein, and polyclonal anti-Cry1 Ab antibodies (PAb). After the immunochemisty steps, the beads were localized onto the surface of the SPEs with the aid of a magnet, prior to the addition of the enzyme substrate (1-naphthylphosphate) and the measurement of the electroactive product. The current response was found to be directly proportional to the concentration of Cry1 Ab protein. The limit of
\end{abstract}

Received 15 December 2005; accepted 20 December 2006

This work was supported by the Ministry of Health, Programma di Ricerca Finalizzata 2002, Project: Metodi analitici rapidi e innovativi per l'analisi e il controllo di OGM ed alimenti contenenti o prodotti a partire da OGM.

Address correspondence to G. Palleschi, Dipartimento di Scienze e Tecnologie Chimiche, Università degli Studi di Roma "Tor Vergata", Roma, Italy. E-mail: giuseppe.palleschi@uniroma2.it 
detection was calculated to be $0.1 \mathrm{ng} \mathrm{mL}^{-1}$ with a working range between 0.25 and $4 \mathrm{ng} \mathrm{mL}^{-1}$ and a total analysis time of about $3 \mathrm{~h}$.

This method, which was also able to detect Cry1Ac protein, was applied to genetically modified corn samples. After optimization of the extraction procedure certified reference materials (CRMs) with different mass fractions $(0.5 \%, 1 \%, 2 \%, 5 \%)$ of dried powder prepared from genetically modified (MON 810) maize, were treated and analyzed in replicate in order to assess, in our conditions, the correspondence between the $\%$ of genetically modified material and the concentration of Cry1 Ab protein $\left(\mathrm{ng} \mathrm{g}^{-1}\right)$. Finally, certified reference material with $0 \%$ of genitically modified organism (GMO), two maize samples with unknown \% of GMO and the two corresponding control samples (with no GMO) were analyzed in order to verify the effectiveness of the IMES-based assay.

Keywords: GMO, screen-printed electrodes, immunomagnetic beads

\section{INTRODUCTION}

Progress in genetic engineering technology has enabled the introduction and expression of novel genes in crop plants in order to produce agronomically useful traits such as insect and disease resistance. The engineered plants are referred to as genetically modified organisms (GMOs) and foodstuffs derived from such crops have been called novel foods. In the context of these developments, several species of crop plants (including cotton, corn, and potato) have been genetically modified to express genes of various subspecies of Bacillus thurigiensis (Bt) encoding insecticidal crystal proteins ( $\delta$-endotoxins) (Head et al. 2002; Lewellyn et al. 1994; Federici 1998). These crystal proteins, which confer protection to the plant from damage by insect herbivores, are designated by the term Cry and a combination of numbers and letters indicating family and subfamily (e.g., Cry1Ab, Cry1Ac, Cry3B, Cry3A). Cry proteins act by disrupting the midgut cells of the insect pest and are highly selective for a specific order (e.g., Cry 1 is specifically toxic to the order Lepidoptera) and are not toxic to beneficial insect, birds, and mammals (Clark et al. 2005; Vaeck et al. 1987).

Three transgenic Lepidoptera-resistant maize lines (Bt-11, MON-810, Bt-176), commonly referred to as $B t$-maize, express the genes for the Bacillus thurigiensis toxins Cry 1Ab (Bt-11, MON-810) and Cry1Ac (Bt-176).

A number of these GMOs have been approved for human consumption, but concerns over safety persist in the public. Allergenicity and toxicity, which are caused by proteins, are the major concerns (Stave 1999).

In the United States there is no mandatory requirement for labeling foods that contain GMOs. However, several countries, including Japan and members of the European Union (EU), have food-labeling laws that incorporate threshold levels. In the EU, foods containing ingredients with a content of GMOs $>0.9 \%$ (for each ingredient) must be labeled (Regulations $1829 / 2003$ and 1830/2003). To enforce these Regulations, reliable and fast 
methods for the detection and quantification of GMOs present in food products are needed. Currently, two different approaches are routinely applied for the detection of GMOs, depending on the specific target chosen: DNA-based detection systems [polymerase chain reaction (PCR and related techniques)] and protein-based detection methods (ELISA and related techniques) (Hubner et al. 1999; Stave 1999; Vaitilingom et al. 1999; Meyer 1999; Lipp et al. 2000; Fagan et al. 2001; Brett et al. 1999; Pasqualone 2000; Walschus et al. 2002). The latter are especially suitable for the analysis of raw materials because industrial transformation processes could cause partial or total degradation of the target protein with consequent failure of detection. Spectrophometric ELISA tests for the quantification of Bt-Cry1Ab end/or Cry1Ac proteins are also commercially available. The current work is focused on the development of an immunomagnetic electrochemical sensor (IMES) for detection of Bt-Cry1 Ab/Cry1 Ac proteins in genetically modified corn samples.

The IMES is based on the use of magnetic beads that are precoated with monoclonal antibody specific for the $\mathrm{Fc}$ region of all mouse $\mathrm{IgG}$, coupled with screen-printed electrodes. The SPEs are miniaturized devices, based on different layers of inks printed on an inert support. Moreover, since they are mass-produced at low cost, they provide for a disposable test strip.

A sandwich scheme was used for the detection of the transgenic protein: $\mathrm{Cry} 1 \mathrm{Ab}$ (standard or treated sample) is sandwiched between the mouse monoclonal anti-Cry1 Ab antibodies (MAb) coated on the surface of IgG-magnetic beads and rabbit polyclonal anti-Cry1 $\mathrm{Ab}$ antibodies $(\mathrm{PAb})$. The sandwich complex was then revealed using anti-rabbit IgG labeled with the enzyme alkaline phosphatase. At the end of all immunological reactions, the immunobeads were localized onto the surface of a magnetized screen-printed electrode and after addition of 1-naphthylphosphate; the enzymatic product (1-naphthol) was measured by use of differential pulse voltammetry (DPV), a fast electrochemical technique.

In the final phase of work, the IMES was applied for detection of the target protein in both certified reference materials and real corn samples. To our knowledge, magnetic beads and an electrochemical detection scheme have not yet been applied to the detection of GMOs.

\section{EXPERIMENTAL}

\subsection{Reagents and Materials}

Cry1Ab, Cry1Ac calibrators, mouse monoclonal antibodies $\left(1 \mathrm{mg} \mathrm{mL}^{-1}\right)$, rabbit polyclonal antibodies $\left(1 \mathrm{mg} \mathrm{mL}^{-1}\right)$ against the target protein and Sample Extraction Buffer were purchased from Abraxis LLC (Warminster, PA, USA); affinity purified anti-rabbit IgG-AP $\left(\mathrm{H}+\mathrm{L}, 3 \mathrm{mg} \mathrm{mL}^{-1}\right)$ were from Vector Laboratories Inc. (Burlingame, CA, USA); nonfat dry milk, blotting grade, was from Bio-Rad Laboratories (Hercules, CA, USA). 
Diethanolamine (DEA) and 1-naphthyl phosphate were purchased from Fluka Chemie, Buchs, Switzerland; Tween 20, certified reference materials (CRMs), produced by IRMM (Institute for Reference Materials and Measurements), with different mass fractions $(0.5 \%, 1 \%, 2 \%, 5 \%)$ of genetically modified (MON 810) maize powder and all other reagents of analytical-reagent grade were obtained from Sigma (St. Louis, MO, USA). Genetically modified corn samples were kindly supplied by partners of the project reported in the acknowledgements of this paper.

Dynadeads ${ }^{\circledR}$ Pan Mouse IgG (supplied as a suspension containing $4 \times 10^{8}$ beads $\mathrm{mL}^{-1}$ in phosphate buffered saline, $\mathrm{pH} 7.4$ ), a rotation device (Dynal sample mixer) and a magnetic particle concentrator (Dynal MPC) were from Dynal, Lake Success, NY.

\subsection{Apparatus}

All DPV measurements were performed using a computer-controlled polarographic analyzer, model 433 A (Amel, Milan, Italy).

The SPEs used for DPV measurements were obtained from Eco Bioservice and Research (Firenze, Italy). The sensor, which consists of a graphite working electrode, a silver pseudo-reference electrode, and a graphite counter electrode, forms a complete electrochemical cell. The diameter of the working electrode was $0.3 \mathrm{~cm}$, which resulted in an apparent geometric area of $0.07 \mathrm{~cm}^{2}$.

\subsection{IMES Procedure}

This proposed method employs a preliminary washing step and an immunoassay procedure followed by electrochemical detection.

\subsubsection{Washing Procedure}

1. Resuspend the Dynabeads Pan Mouse IgG thoroughly in the vial;

2. Transfer $10 \mu \mathrm{L}$ of beads into a $2 \mathrm{~mL}$ eppendorf tube (for each Cry $1 \mathrm{Ab}$ concentration to analyze);

3. Place the tubes in the Dynal MPC for 1 minute and pipette off the liquid;

4. Remove the tubes from the Dynal MPC, add $1 \mathrm{~mL}$ of washing buffer $[(\mathrm{PBS} \mathrm{pH} 7.4+0.1 \%(\mathrm{w} / \mathrm{v})]$ BSA;

5. Repeat in succession step $3,4,3$.

\subsubsection{Immunoassay Procedure}

Dynabeads were then used as a solid phase in the sandwich immunoassay employing the following steps:

1. Block the surface of the beads with $1 \mathrm{~mL}$ of $3 \%$ dry milk suspension for $30 \mathrm{~min}$ (to avoid nonspecific adsorptions of the reagents); 
2. Add $400 \mu \mathrm{L}$ of MAb solution $\left(1 \mu \mathrm{g} \mathrm{mL}^{-1}\right)$ for $30 \mathrm{~min}$;

3. Add $400 \mu \mathrm{L}$ of Cry1 Ab standard solutions $(0,0.25,0.5,1,2$, and $4 \mathrm{ng} \mathrm{mL}^{-1}$ ) for $30 \mathrm{~min}$;

4. Add $400 \mu \mathrm{L}$ of PAb solution $\left(4 \mu \mathrm{g} \mathrm{mL}^{-1}\right)$ for $30 \mathrm{~min}$;

5. Add $400 \mu \mathrm{L}$ of $\mathrm{Ab}_{2}$-AP solution $\left(10 \mu \mathrm{g} \mathrm{mL}^{-1}\right)$ for $30 \mathrm{~min}$;

6. Wash two times with $1 \mathrm{~mL}$ of PBS pH $7.4+0.05 \%$ (w/v) Tween 20 and one time with PBS only.

The solutions for steps $1-5$ were prepared in PBS and the incubation was performed with slow tilt rotation using the Dynal sample mixer. Between each step (1-6) the tubes were place in the Dynal MPC for 1 minute and the liquid was pipetted off. Finally the immunobeads (IMBs) were resuspended in $100 \mu \mathrm{L}$ of PBS.

For electrochemical measurements, $100 \mu \mathrm{L}$ of the IMBs' suspension were placed on the surface of the SPE. The beads were magnetically trapped against the working electrode surface (with the aid of a small magnet placed underneath) for two minutes and the liquid was removed by aspiration. The sandwich complex was revealed by adding $70 \mu \mathrm{L}$ of the substrate solution $\left[1 \mathrm{mg} \mathrm{ml}^{-1}\right.$ of 1-naphthyl phosphate in $0.97 \mathrm{M}$ diethanolamine buffer (DEA), $\left.\mathrm{pH} 9.8+1 \mathrm{mM} \mathrm{MgCl}_{2}+0.15 \mathrm{M} \mathrm{KCl}\right]$ to cover the three-electrode system. After $2 \mathrm{~min}$ of incubation, the current response was measured with DPV. Electrochemical measurements were performed in the potential range $0-+600 \mathrm{mV}$ vs. the silver screen-printed pseudo-reference electrode, with a modulation time (pulse length) of $60 \mathrm{~ms}$, a modulation amplitude (pulse amplitude) of $50 \mathrm{mV}$, and a scan speed of $100 \mathrm{mV} \mathrm{s}^{-1}$.

The scheme of the entire IMES procedure is reported in Fig. 1.

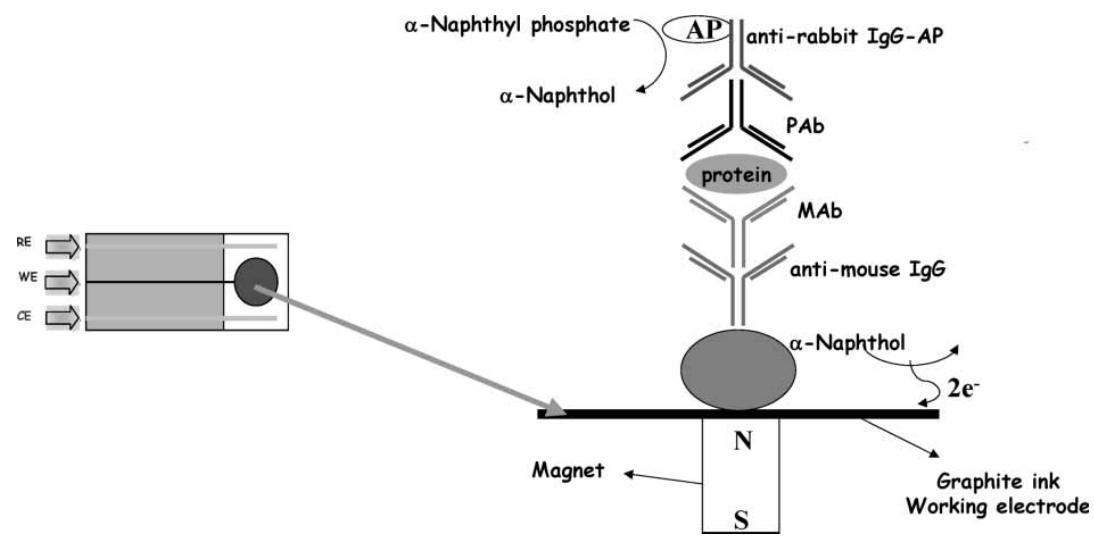

Figure 1. Scheme of the IMES system. 


\subsection{Sample Treatment}

Maize seeds were put in a mortar and ground with a pestle until the tissue was well converted to a powder. Cry1 Ab protein was extracted from the resulting powder using the following procedure:

1. Weigh $1.0 \mathrm{~g}$ of powder;

2. Add $2 \mathrm{~mL}$ of sample extraction buffer;

3. Shake for $5 \mathrm{~min}$ using the rotary sample mixer;

4. Centrifuge for $10 \mathrm{~min}$ at $6000 \mathrm{~g}$;

5. Carefully remove the supernatant.

The supernatant was then used for the IMES test.

In the case of the certified reference materials, purchased as a fine powder, the same extraction procedure was followed.

\section{RESULTS AND DISCUSSION}

After a preliminary phase in which the functionality of the MAb and PAb antibodies were tested in a conventional spectrophotometric plate, the antibodies were first employed to develop an electrochemical sensor based on a sandwich format in which the immunological chain took place directly on the working electrode surface of the SPE, without the use of magnetic beads. Because this disposable immunosensor was able to detect $1 \mathrm{ng} \mathrm{mL}^{-1}$ of Cry1 Ab protein as a minimum concentration level in about 4 hours, IMBs coupled with screenprinted electrodes were tested in order to improve the detection limit, and also for a simpler and more rapid detection of transgenic Bt-Cry $1 \mathrm{Ab} / \mathrm{Cry} 1 \mathrm{Ac}$ proteins.

Parameters such as antibody concentration (MAb, PAb, and $\mathrm{Ab}_{2}-\mathrm{AP}$ ), blocking agents, intermediate washing steps (essential for a conventional ELISA), and incubation time were evaluated. Because, for the development of immunoassays based on the use of IMBs, differing protocols concerning the blocking phase and the intermediate washings to adopt between each step are reported in the literature, these two parameters have been investigated to evaluate their influence on nonspecific adsorption of the biocomponents on the IMB surface. Results demonstrate the indispensability of the blocking phase and the uselessness of the intermediate washings. In fact, in this last condition (see Fig. 2) we obtained the highest current variations between $\mathrm{Cry} 1 \mathrm{Ab}=2 \mathrm{ng} \mathrm{mL}^{-1}$ (measured with the proposed sandwich scheme) and the corresponding blanks performed in the same conditions but without $\mathrm{MAb}$ coating or Cry1 Ab protein (zero point). Therefore, this procedure was adopted making the test more rapid. The interaction times between the bioreagents (IgG anti-mouse/MAb/Cry $1 \mathrm{Ab} / \mathrm{PAb} / \mathrm{Ab}_{2}-\mathrm{AP}$ ) were such that it was possible to carry out the entire protocol in about three hours.

Moreover, an investigation of the effect of varying dilutions of MAb $\left(2 \mu \mathrm{g} \mathrm{mL}^{-1}-0.2 \mu \mathrm{g} \mathrm{mL}^{-1}\right) \quad \mathrm{PAb} \quad\left(8 \mu \mathrm{g} \mathrm{mL}^{-1}-1 \mu \mathrm{g} \mathrm{mL}^{-1}\right)$ and $\mathrm{Ab}_{2} \mathrm{AP}$ 

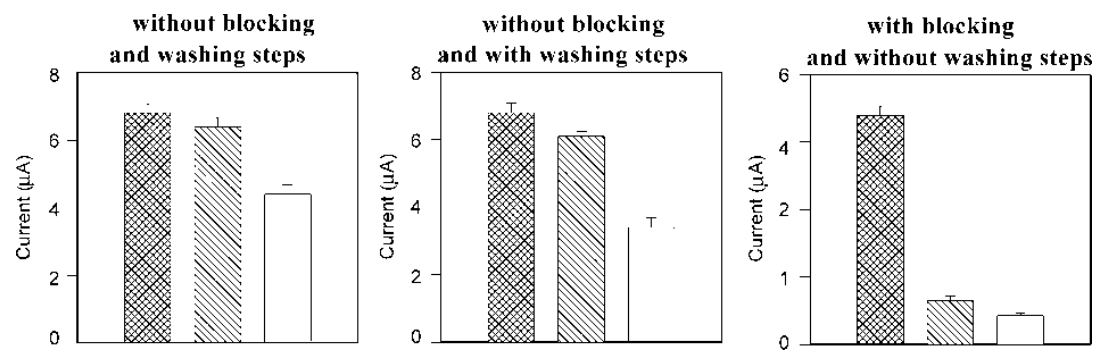

Figure 2. Estimation of the blocking phase and washings to adopt between each step of the immunological chain using IgG-IMBs as immobilization support. $6 \times 8 \mathrm{MAb}$ $\left(1 \mu \mathrm{g} \mathrm{mL}^{-1}\right)$, Cry1 Ab $\left(2 \mathrm{ng} \mathrm{mL}^{-1}\right), \mathrm{Pab}\left(4 \mu \mathrm{g} \mathrm{mL}^{-1}\right), \mathrm{Ab}_{2}-\mathrm{AP}\left(10 \mu \mathrm{g} \mathrm{mL}^{-1}\right) \square \circlearrowright$ No MAb coating, Cry1Ab $\left(2 \mathrm{ngm}^{-1}\right), \mathrm{Pab}\left(4 \mu \mathrm{g} \mathrm{mL}^{-1}\right), \mathrm{Ab}_{2}$-AP $\left(10 \mu \mathrm{g} \mathrm{mL}^{-1}\right)$ — MAb $\left(1 \mu \mathrm{g} \mathrm{mL}^{-1}\right)$, No Cry1Ab, Pab $\left(4 \mu \mathrm{g} \mathrm{mL}^{-1}\right), \mathrm{Ab}_{2}-\mathrm{AP}\left(10 \mu \mathrm{g} \mathrm{mL}^{-1}\right)$.

(20 $\left.\mu \mathrm{g} \mathrm{mL}^{-1}-1 \mu \mathrm{g} \mathrm{mL}^{-1}\right)$ demonstrated that the selected concentrations, reported in the IMES procedure section, gave the maximum electrochemical signals, while no further current variations were observed for the higher concentrations tested.

The calibration curve for $\mathrm{Cry} 1 \mathrm{Ab}$ protein under the optimized experimental conditions is reported in Fig. 3, each value being the mean of three determinations. It can be observed that at the conclusion of the immunological chain, the amount of label associated with the solid phase (beads) is directly related to the concentration of the target antigen. The experimental data were fitted using a second order equation $\left(\mathrm{y}=\mathrm{ax}^{2}+\mathrm{bx}+\mathrm{c}\right)$ giving a regression coefficient $\left(\mathrm{R}^{2}\right)$ of 0.99 . The detection limit, defined as the concentration corresponding to the y value obtained by adding three standard deviations of zero, point to the mean of the zero standard measurement (mean value $+3 \mathrm{sd}$ ) result, which was found to be $0.1 \mathrm{ng} \mathrm{mL}^{-1}$, while the working range was between 0.25 to $4 \mathrm{ng} \mathrm{mL}^{-1}$.

The IMES is also able to detect the presence of Cry1 Ac protein. Two calibration curves for Cry $1 \mathrm{Ab}$ and Cry $1 \mathrm{Ac}$ were performed in parallel. In Table 1 the concentrations of Cry1Ac equivalent to the given concentrations of $\mathrm{Cry} 1 \mathrm{Ab}$ are reported. No cross-reactivity or very little cross-reactivity was observed towards other Cry proteins. Although the test is more sensitive to Cry1Ac protein, we decided to express the total content of Cry $1 \mathrm{Ab} / 1 \mathrm{Ac}$ proteins as Cry $1 \mathrm{Ab}$. In this way, for the analysis of unknown maize samples, the use of Cry $1 \mathrm{Ab}$ calibration curve avoids false negative results, thus protecting the health of the consumers.

\subsection{Corn Samples Analysis}

The majority of kits commercially available for GMO analysis suggest the use of calibration curves constructed with certified reference materials, but this 


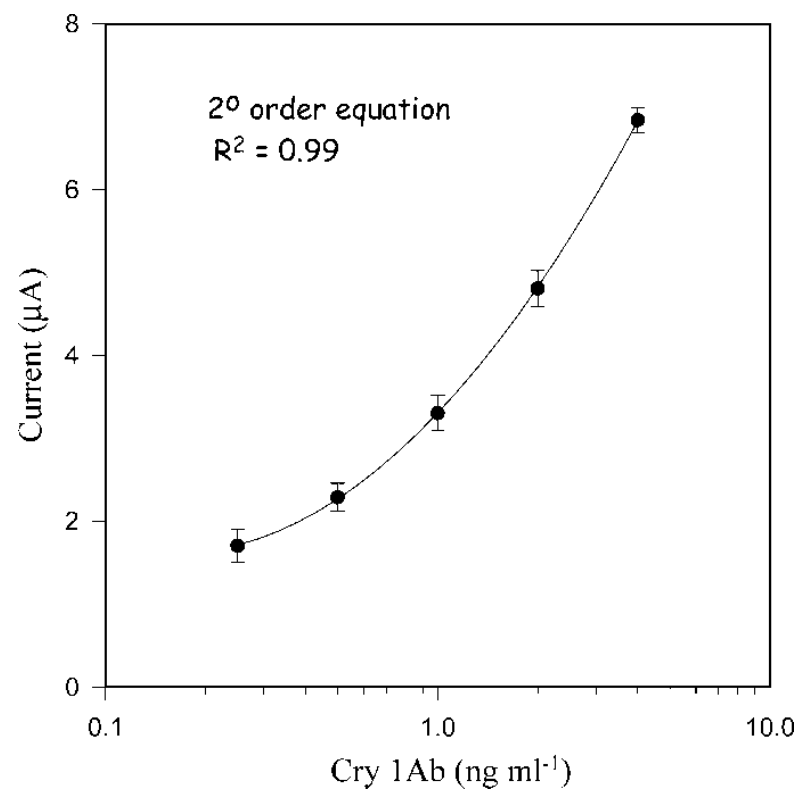

Figure 3. Calibration curve for Cry1 Ab protein, each value is the mean of three measurements.

procedure becomes very expensive for routine analysis in which daily calibration curves are needed. For this reason we decided to use Cry1 Ab calibrators and to assess the correspondence between the $\%$ of genetically modified material and the concentration of Cry $1 \mathrm{Ab}$ protein $\left(\mathrm{ng} \mathrm{g}^{-1}\right)$ in our experimental conditions. This correspondence is not reported in the literature to our knowledge.

For this purpose, two aliquots of certified reference materials having different mass fractions $(0.5,1,2)$ of genetically modified (MON 810) maize powder, were extracted and analyzed on each of three different days [for each concentration level $n=12$ ( 2 replicates $\times 3$ days $\times 2$ electrodes)] usingCry $1 \mathrm{Ab}$ protein as calibrator. In Fig. 4 the obtained correlation straight line is reported. Once obtained, this straight line can be used for all the successive GMO measurements.

Table 1. Concentrations (ng $\mathrm{mL}^{-1}$, mean of three determination) of $\mathrm{Cry} 1 \mathrm{Ac}$ endotoxin equivalent to the given concentrations of Cry1 Ab

\begin{tabular}{lllll}
\hline Cry $1 \mathrm{Ab}$ & 0.5 & 1.0 & 2.0 & 4.0 \\
Cry $1 \mathrm{Ac}$ & 0.3 & 0.5 & 1.0 & 2.1 \\
\hline
\end{tabular}




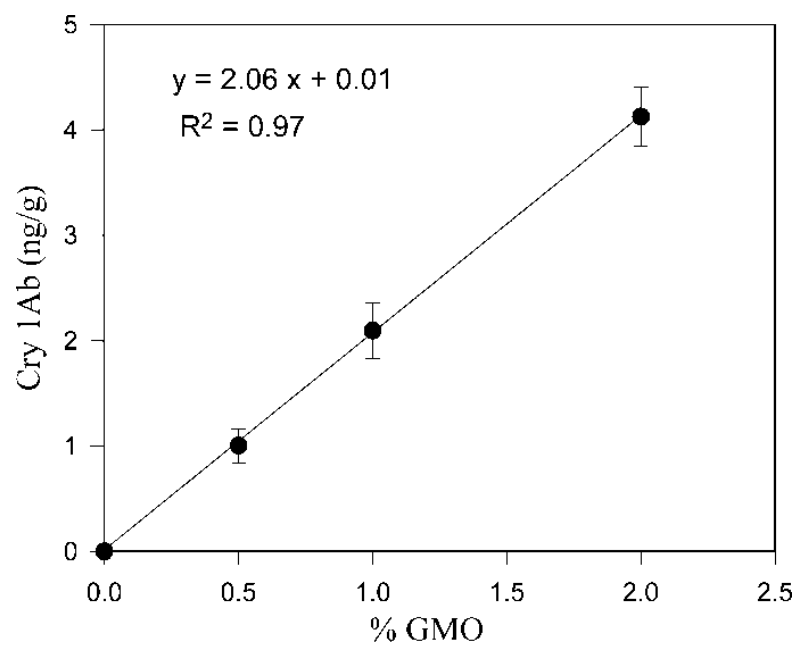

Figure 4. Correlation strait line between $\%$ of $\mathrm{GMO}$ and $\mathrm{ng} \mathrm{g}^{-1}$ of Cry $1 \mathrm{Ab}$ protein, obtained in our experimental conditions.

In a succeeding phase, certified reference material with $0 \%$ of GMO, two maize samples (to belong to hybrid lines of MON 810, named MO17 and B73 Bt respectively) with unknown \% of GMO, and the two corresponding control samples (with no GMO) were analyzed and the concentration of Cry1 Ab was determined. Then, by plotting the obtained values on the correlation straight line (concentration of protein vs. \% of GMO) the \% of GMO was estimated (indirect method). For comparison, the \% of GMO in the same samples was also evaluated using calibration graphs performed with certified reference materials (direct method). The results are reported in Table 2. As can be seen, results obtained using direct and indirect methods are in good agreement.

Table 2. Corn samples analysis $(\mathrm{n}=3)$

\begin{tabular}{lccc}
\hline Sample name & $\begin{array}{c}\text { Cry1 Ab } \\
\left(\mathrm{ng} \mathrm{g}^{-1}\right) \\
(\text { mean } \pm \mathrm{sd})\end{array}$ & $\begin{array}{c}\% \text { GMO } \\
\text { (mean } \pm \mathrm{sd}) \\
\text { by indirect } \\
\text { method }\end{array}$ & $\begin{array}{c}\% \text { GMO } \\
(\text { mean } \pm \mathrm{sd}) \\
\text { by direct } \\
\text { method }\end{array}$ \\
\hline $\begin{array}{l}\text { Certified reference } \\
\text { material (0\% GMO) }\end{array}$ & n.d. & n.d. & n.d. \\
$\begin{array}{l}\text { MO17 } \\
\text { MO17 bank control }\end{array}$ & $179 \pm 24$ & $87 \pm 14$ & $100 \pm 12$ \\
B73Bt & n.d. & n.d. \\
B73 Bt blank control & $\begin{array}{c}\text { n.5 } \pm 1.2 \\
\text { n.d. }\end{array}$ & $\begin{array}{c}3.2 \pm 0.7 \\
\text { n.d. }\end{array}$ & $\begin{array}{c}3.8 \pm 0.7 \\
\text { n.d. }\end{array}$ \\
\hline
\end{tabular}




\section{CONCLUSIONS}

In this paper the development of an immunomagnetic electrochemical sensor (IMES) for the simple and rapid detection of Bt-Cry1 Ab/Cry1 Ac proteins in genetically modified corn samples is presented. It is based on the use of immunomagnetic beads as immobilization support, screen-printed electrodes as electrochemical transducers, and Cry1 Ab protein as calibrators.

After a preliminary optimization phase for analytical parameters and sample extraction, the optimal conditions were used to assess the correspondence between the $\%$ of genetically modified material and the concentration of Cry1 $\mathrm{Ab}$ protein $\left(\mathrm{ng} \mathrm{g}^{-1}\right)$, so that the correlation straight line can be used for an indirect quantification of the \% of GMO in corn samples.

This method is less expensive then the direct method, based on the use of certified reference material as calibrators.

Although the performances of the immunomagnetic electrochemical sensor, in terms of detection limit and total analysis time, are comparable to those of commercially available spectrophotometric kits, the proposed method represents a new and attractive approach for GMO analysis.

\section{REFERENCES}

Brett, G.M., Chambers, S.J., Huang, L., and Morgan, M.R.A. 1999. Design and development of immunoassays for detection of proteins. Food Control, 10: 401-406.

Clark, B.W., Phillips, T.A., and Coats, J.R. 2005. Environmental fate and effects of Bacillus thurigiensis (Bt) proteins from transgenic crops: a review. J. Agric. Food Chem., 53: 4643-4653.

Fagan, J. et al. 2001. Performance assessment under field conditions of a rapid immunological test for transgenic soybeans. Int. J. Food Sci. Technol., 36: 1-11.

Federici, B. 1998. Broadscale use of pest-killing plants to be true test. Calif. Agric, 52: 14-20.

Head, G., Surber, J.B., Watson, J.A., Martin, J.W., and Duan, J.J. 2002. No detection of Cry 1Ac protein in soil after multiple years of transgenic Bt cotton (Bollgard) use. Environ. Entomol., 31 (1): 30-36.

Hubner, P., Studer, E., and Luthy, J. 1999. Quantitative competitive PCR for the detection of genetically modified organisms in food. Food Control, 10: 353-358.

Lewellyn, D., Cousins, Y., Mathews, A., Hartweek, L., and Lyon, B. 1994. Expression of Bacillus thurigiensis insecticidal protein genes in transgenic crop plants. Agric. Ecosys. Environ., 49: 85-93.

Lipp, M. et al. 2000. Validation of an immunoassay for the detection and quantification of Roudup-Ready soybeans in food and food fractions by the use of reference material. J. AOAC Int., 83: 99-127.

Meyer, R. 1999. Development and application of DNA analytical methods for the detection of GMOs in food. Food Control, 10: 391-399.

Pasqualone, A. 2000. Metodi di analisi per la rivelazione di OGM negli alimenti. Industrie Alimentari, XXXIX (aprile): 444-451.

Stave, J.M. 1999. Detection of new or modified proteins in novel food derived from GMO-future needs. Food Control, 10: 367-374. 
Vaeck, M., Reynaerts, A., Hofte, H., Jansens, S., De Beuckeleer, J., Dean, C., Zabeau, M., Van Montagu, M., and Leemans, J. 1987. Transgenic plants protected from insect attack. Nature, 328: 33-37.

Vaitilingom, M. et al. 1999. Real-time quantitative PCR detection of genetically modified maximizer maize and Roundup Ready Soybean in some representative foods. J. Agric. Food Chem., 47: 5261-5266.

Walschus, U., Witt, S., and Wittmann, C. 2002. Development of monoclonal antibody against Cry $1 \mathrm{Ab}$ protein from Bacillus thurigiensis and their application in an ELISA for detection of transgenic Bt-Maize. Food Agric. Immunol., 14 (2): 231-240. 